The 49th Annual Conference of the International Association of School Librarianship

The 24th International Forum on Research on School Librarianship

July $12-16,2021$

Maria Cahill, Bobbie Sartin Long, Denice Adkins

\title{
Services for Preschool Children in School Libraries: A Call to Action
}

\section{Introduction}

The quality of learning environments and interactions in the first years of life set the stage for school success and have lasting impacts on mental and physical health and wellbeing across the lifespan, and even life expectancy (Wong, Odom, Hume, Cox, Fettig, et al, 2014; Reynolds et al., 2011). Libraries are positioned to provide rich learning opportunities for young children and their caregivers (Institute of Museum and Library Services, 2013, 2015; Urban Libraries Council, 2007). Library programs for young children, offered in nearly all public libraries in the United States support school readiness and educate parents about meaningful ways to interact with their children (Becker, 2012; Burger \& Landerholm, 1991; Cahill, Joo, \& Campana, 2019; Campana et al., 2016; de Vries, 2008; McKechnie, 2006; Mills et al., 2018; Smardo, 1984; Williams, 1998), but it is unclear what, if any, programs are offered for young children and their families through school libraries.

Keywords: children with disabilities, school libraries, school librarians

\section{Introduction}

The Individuals with Disabilities Education Act (IDEA) (2004) mandates a free public education to all children in the United States (U.S.) ages birth to 21 years who have one or more disabilities. Infants and toddlers receive early intervention services (Part C), while those ages 3 through 21 receive special education and related services (Part B). According to the National Center for Education Statistics (US Department of Education, 2019), 13.7\% of the total school aged population in the U.S. receives disability services through Part B.

\section{Statement of the Research Problem}

Section 619 of IDEA describes funding for state and local programs, and state-level administration and activities to support children with disabilities ages three through five. Nearly $7 \%$ of the total population of children 3-5 years of age in the United States receives disability services through IDEA, Part B, section 619 (United States Department of Education, 2019), and approximately $60 \%$ of those receiving services attend an early childhood program or other school. Yet, it is unclear what, if any, library programs and services these children or any other children in publicly funded preschool and early childhood education programs receive. 


\section{Literature Review}

Little empirical information exists regarding school library service for preschool children. When school library services are offered, preschool children learn important skills and tend to enjoy the experience (Cahill, 2004); however, the one study that examined access to school libraries for children enrolled in public school prekindergarten programs found that the majority receive no services at all (Tullio, 2006).

The professional literature addressing programming and services for young children with disabilities and/or development delays in school libraries is even sparser. A recent investigation of public librarians' practices with preschool children with special needs (Cahill, Joo, \& Howard, 2019), conducted as part of a larger investigation of public library storytime programs, found that some public libraries offer outreach programs to early childhood classrooms that serve children with disabilities and developmental delays. The bulk of literature addressing programming and services for school age children with disabilities promotes inclusion as a general ideal (e.g. Adams, 2009; Downing, 2006; Jurkowski, 2006; Neal \& Ehlert, 2006) or simply describes programs or services that have been implemented for children who qualify for special education. No empirical investigations of school library services for children with disabilities (Allen \& Hughes-Hassel, 2010; Cox \& Lynch, 2006; Heeks \& Kinnell, 1997; Markey \& Miller, 2015; Murray, 2002; Perrault, 2011a; Small, Snyder, Parker, 2009) have been focused on preschool children (ages 3-5) who qualify for special education services through IDEA. Thus, while school librarians should play a role in the education and social and emotional support of young children with disabilities and developmental delays who qualify for preschool services (Jurkowski, 2006), it is unclear if they do. Further, school librarians admit a lack of appropriate resources and professional knowledge to serve children with disabilities well (Allen \& Hughes-Hassell, 2010; Cox \& Lynch, 2006; Perrault, 2011b; Small, Snyder, \& Parker, 2009).

\section{Discussion}

That lack of access to library services and programs for young children with special needs is particularly concerning given that the home literacy environments of children with disabilities are significantly less supportive than those of their typically developing peers (Boudreau, 2005; van der Schuit, Peeters, Segers, van Balkom, \& Verhoeven, 2009). Specifically, some studies report that children with disabilities have less access to books and other literacy materials than their typically developing peers (Light \& Kelford Smith, 1993; Marvin, 1994; Marvin \& Mirenda, 1993), and access to books and other literacy materials tends to decline in relation to the severity of a disability (Carlson, Bitterman, \& Jenkins, 2012). Given the existing inadequacy of the home literacy environments of many young children with disabilities, library programs

and services have the potential to be even more important for this segment of the population. As Downing (2006) contends, children with disabilities should not only have access to library 
services and programs equal to that of their normally developing peers, they should ideally have more.

Three decades ago, a public library children's services consultant regretfully declared, "libraries and librarians have been overlooked and underutilized as resources for children with learning differences" (Rovenger, 1987, p. 428). Yet, health professionals who provide early intervention services for young children with disabilities and developmental delays recognize the beneficial nature of libraries as supportive community resources (Ordonez-Jasis \& Myck-Wayne, 2012). Promisingly, library communities internationally recognize inclusion of people with disabilities as a challenge area and are taking measures to discuss and overcome it (Djonov, Torr, \& Stenglin, 2018). School library scholars and school library leaders should consider following the lead of the larger library community and begin championing school library services and programs for young children with special needs. Additional research investigating library services and programs available for young children is necessary to support these efforts.

\section{References}

Adams, H. R. (2009). Access for students with disabilities. School Library Media Activities, 25(10), 54 .

Allen, K. L., \& Hughes-Hassel, S. (2010). Meeting the needs of students with disabilities. School Library Media Activities, 27(1), 52-54.

Becker, K. (2012). 24 hours in the children's section: An observational study at the public library. Early Childhood Education Journal, 40, 107-114.

Boudreau, D. (2005). Use of a parent questionnaire in emergent and early literacy assessment of preschool children. Language, Speech and Hearing Services in Schools, 36(1), 33-47.

Burger, M. L., \& Landerholm, E. (1991). A library based literacy program for mothers and their preschool children. Early Child Development and Care, 70(1), 37-43.

Cahill, M. (2004). Meeting the early literacy needs of children through preschool outreach storytime programs. Knowledge Quest, 33, 61-62.

Cahill, M., Joo, S., \& Campana, K. (2019). Analysis of language use in public library storytimes. Journal of Librarianship \& Information Science. https://doi.org/10.1177/0961000618818886

Cahill, M., Joo, S., \& Howard, M. (2019, August). Value and diversity in storytime. Paper presented at Indiana Library Federation Youth Services Conference, Carmel, IN.

Campana, K., Mills, J.E., Capps, J.L., Dresang, E.T., Carlyle, A, et al. (2016). Early literacy in library storytimes: A study of measures of effectiveness. Library Quarterly 86(4), 369-388.

Carlson, E., Bitterman, A., \& Jenkins, F. (2012). Home literacy environment and its role in the achievement of preschoolers with disabilities. The Journal of Special Education, 46(2), $67-77$. 
Cox, J. E., \& Lynch, D. M. (2006). Library media centers: Accessibility issues in rural Missouri. Intervention in School and Clinic, 42(2), 101-106.

de Vries, P. A. (2008). Parental perceptions of music in storytelling sessions in a public library. Early Childhood Education Journal, 35, 473-478.

Djonov, E., Torr, J., \& Stenglin, M. (2018). Early language and literacy: Review of research with implications for early literacy programs at NSW public libraries. Sydney, Australia: Macquarie University and State Library of New South Wales.

Downing, J. A. (2006). Media centers and special education: Introduction to the special issue. Intervention in School and Clinic, 42(2), 67-77.

Heeks, P., \& Kinnell, M. (1997). Learning support for all? Special needs pupils and learning resources. Journal of Librarianship and Information Science, 29(3), 143-153.

Individuals with Disabilities Education Act, 20 U.S.C. $§ 1400$ (2004).

Institute of Museums and Library Services. (2013). Growing young minds: How museums and libraries create lifelong learners. Washington, DC: Author.

Institute of Museums and Library Services. (2015). Learning in libraries. Washington, DC: Author.

Jurkowski, O. L. (2006). The library as a support system for students. Intervention in School and Clinic, 42(2), 78-83.

Light, J. \& Kelford Smith, A. (1993). Home literacy experiences of preschoolers who use AAC systems and of their nondisabled peers. Augmentative and Alternative Communication, 9(1), 10-25.

Markey, P. T., \& Miller, M. L. (2015). Introducing an information-seeking skill in a school library to students with autism spectrum disorder: Using video modeling and least-to-most prompts. School Library Research, 18.

Marvin, C. (1994). Home literacy experiences of preschool children with single and multiple disabilities. Topics in Early Childhood Special Education, 14(4),436-454.

Marvin, C., \& Mirenda, P. (1993). Home literacy experiences of preschoolers enrolled in Head Start and special education programs. Journal of Early Intervention, 17(4), 351-367.

McKechnie, L. E. F. (2006). Observations of babies and toddlers in library settings. Library Trends, 55(1), 190-201.

Mills, J. E., Campana, K., Carlyle, A., Kotrla, B., Dresang, E. T., et al. (2018). Early literacy in library storytimes, part 2: A quasi-experimental study and intervention with children's storytime providers. Library Quarterly, 88(2), 160-176.

Murray, J. (2002). The implications of inclusive school for school libraries. International Journal of Disability, Development, and Education, 49(3), 301-322.

Neal, J. D., \& Ehlert, D. (2006). Add technology for students with disabilities to the library media center. Intervention in School and Clinic, 42(2), 119-123.

Ordonez-Jasis, R., \& Myck-Wayne, J. (2012). Community mapping in action: Uncovering resources and assets for young children and their families. Young Exceptional Children, $15(3), 31-45$. 
Perrault, A. M. (2011). Reaching all learners: Understanding and leveraging points of intersection for school librarians and special education teachers. School Library Research, 14.

Perrault, A. M. (2011b). Rethinking school libraries: Beyond access to empowerment. Knowledge Quest, 39(3), 6-7.

Reynolds, A. J., Temple, J. A., Ou, S-R., Arteaga, I. A., \& White, B. A. B. (2011). School-based early childhood education and age-28 well-being: Effects by timing, dosage, and subgroups. Science, 333(6040), 360-364.

Rovenger, J. (1987). Learning differences/library directions: Library service to children with learning differences. Library Trends, 35(3), 427-435.

Small, R. V., Snyder, J., \& Parker, K. (2009). The impact of New York's school libraries on student achievement and motivation: Phase 1. School Library Media Research, 12.

Smardo, F. (1984). What research tells us about storyhours and receptive language. Texas Libraries, 45(2), 52-56.

United States Department of Education. National Center for Education Statistics. (2019). Table 204.70. Number and percentage of children served under Individuals with Disabilities Education Act (IDEA), Part B, by age group and state or jurisdiction: Selected years, 1990-91 through 2017-18. Digest of Education Statistics. Retrieved from https://nces.ed.gov/programs/digest/d18/tables/dt18_204.70.asp

United States Department of Education. (2019). Children ages 3 through 5 served under IDEA, Part B, as a percentage of population, by disability category and state. IDEA Section 618 Data Products: Static Tables. Retrieved from https://www2.ed.gov/programs/osepidea/618-data/static-tables/index.html

Urban Libraries Council. (2007). Making cities stronger: Public library contributions to local economic development. Evanston, IL: Author.

Tullio, M. (2006). Pre-k student and teacher access to and use of school library media programs. [Unpublished master's thesis. Rowan University, Glassboro, NJ].

van der Schuit, M., Peeters, M., Segers, E., van Balkom, H., \& Verhoeven, L. (2009). Home literacy environment of preschool children with intellectual disabilities. Journal of Intellectual Disability Research, 53(12), 1024-1037.

Williams, A. J. (1998). Providers' perceptions of public library storytime: A naturalistic inquiry. [Unpublished doctoral dissertation, University of Texas, Austin, Tx].

Wong, C., Odom, S. L., Hume, K., Cox, A. W., Fettig, A., et al. (2014). Evidence-based practices for children, youth, and young adults with autism spectrum disorder. Chapel Hill, NC: The University of North Carolina, Frank Porter Graham Child Development Institute, Autism Evidence-Based Practice Review Group. 